\title{
Serum calcium and lipid profile in acute ischemic stroke Sharmin $N^{1}$, Sultana $N^{2}$, Mazumder $P^{3}$, Rahman $T^{4}$
}

\begin{abstract}
:
Background: Worldwide acute ischemic stroke (AIS) is a major public health problem. Therefore, this study was undertaken to see the association of some biochemical risk factors with AIS in Bangladesh. Methodology: This study was conducted in Biochemistry department of Dhaka Medical College, Dhaka from January 2014 to December 2014. In this study, 50 patients of AIS considered as case and 50 age and sex matched healthy individuals taken as control. Blood sample was collected and tested for serum calcium and lipid profile in case and control. All the parameters then compared statistically between two groups. Results: Study showed that serum calcium was significantly lower $(\mathrm{p}=0.001)$ in cases and serum TChol, TAG, LDL-C significantly higher ( $\mathrm{p}=0.035,0.001$ and 0.019 respectively) and HDL-C significantly lower (0.001) in cases compared to controls. Conclusions: This study concludes that low serum calcium level and altered lipid profile are significantly associated with AIS.
\end{abstract}

Keywords: serum calcium; lipid profile; acute ischemic stroke

Bangladesh Journal of Medical Science Vol.14(3) 2015 p.286-289 DOI: http://dx.doi.org/10.3329/bjms.v14i3.23479

\section{Introduction:}

Acute ischemic stroke is a globally increasing health problem. It is ranked after heart disease and before cancer. Stroke was the second most frequent cause of death worldwide in 2011. Between 1990 and 2010 the number of strokes decrease by approximately $10 \%$ in the developed world and increased by $10 \%$ in the developing world ${ }^{1 .}$

Generally, it is recognized that stroke is a multifactorial condition. A number of risk factors have been shown to be associated with stroke are age, high blood pressure, hypercholesterolemia, previous history of stroke or, transient ischemic attack, diabetes mellitus, obesity and dietary factors, atrial fibrillation and tobacco smoking ${ }^{2}$. Risk of stroke increases with age, especially in patients older than 64 years ${ }^{3}$. Along with these factors low serum calcium has been found to be associated with ischemic stroke by many researchers. Calcium plays an important role in the pathogenesis of acute ischemic stroke. In ischemic stroke, excessive intracellular Calcium accumulation triggers a cascade of cytotoxic events that lead to the activation of enzymes involved in the cell death.
Plasma calcium is a predictor of $\mathrm{CVD}^{4}$. A cross sectional study showed that increased calcium intake decreased the risk of several CVD risk factors ${ }^{5}$. Some study reveal that lower Calcium levels may be associated with more severe clinical symptoms on admission in acute stroke patient ${ }^{6}$. Highest Calcium levels also correlated with a $50 \%$ to $70 \%$ lower risk of poor functional outcome. Another animal studies have demonstrated that Calcium administration can reduce both infract size and stroke related mortality ${ }^{7}$. High dietary intake of Calcium has been associated with reduced risk of stroke . $^{8}$

A web document shows that a high level of total cholesterol $(\geq 240 \mathrm{mg} / \mathrm{dl})$ in the blood raises the risk of stroke. Recent some other studies revealed that high levels of LDL cholesterol $(>100 \mathrm{mg} / \mathrm{dl})$ and triglycerides $(\geq 150 \mathrm{mg} / \mathrm{dl})$ directly increase the risk of stroke in people with previous coronary heart disease, ischemic stroke or TIA ${ }^{9}$. Epidemiological studies have shown that high concentrations of HDL (over $60 \mathrm{mg} / \mathrm{dl}$ ) have protective value against ischemic stroke and low concentrations of HDL (below $40 \mathrm{mg} / \mathrm{dl}$ for men and below $50 \mathrm{mg} / \mathrm{dl}$ for

1. Dr. Nazia Sharmin, Assistant professor, Department of Biochemistry, Monno Medical College, Manikganj.

2. Prof. Dr. Nasima Sultana, Professor, Department of Biochemistry, Dhaka Medical College, Dhaka.

3. Dr. Pinke Mazumder, Assistant professor, Department of Biochemistry, Army Medical College, Bogra.

4. Dr. Taniza Rahman, Assistant professor, Department of Biochemistry, Ashian Medical College, Dhaka.

Corresponds to: Dr. Nazia Sharmin, Assistant professor, Department of Biochemistry, Monno Medical College, Manikganj. 
women) increase the risk for atherosclerotic diseases. The association between low HDL cholesterol and risk of ischemic stroke was very strong and HDL cholesterol remains the strongest risk factor ${ }^{10}$.

But most of these data are from developed countries. Very few data are available in our country regarding this topic. Therefore, we assessed the association of serum calcium level and lipid profile in AIS cases of Bangladesh.

\section{Materials and methods:}

A case control study was carried out in the Department of Biochemistry, Dhaka Medical College, Dhaka from January 2014 to December 2014. A total 100 subjects participated in this study. Among them, 50 diagnosed cases of AIS and 50 age and sex matched healthy individuals were selected as control purposively according to selection criteria. The diagnosis of acute ischemic stroke was confirmed by Computed Tomography Scan of brain. A questionnaire was used to collect information regarding age, family $\mathrm{H} / \mathrm{O}$ stroke, H/O HTN and DM, relevant drug history, the height and weight of individuals to calculate BMI. For the measurement of serum calcium level and lipid profile, $5 \mathrm{ml}$ of fasting venous blood sample were collected after all aseptic precautions by disposable plastic syringe without using any tourniquet from all the study subjects. Then mean values of the quantitative variables were compared between case and control by unpaired student's t-test. Results were analyzed statistically in SPSS version 20 for windows expressed as mean \pm SD. P value $<$ 0.05 was considered as significant.

\section{Results:}

Table-I: Demographic characteristics of the subjects

\begin{tabular}{|l|l|l|l|}
\hline variables & $\begin{array}{l}\text { Case } \\
(\mathrm{n}=50) \\
(\text { Mean } \pm \text { SD) }\end{array}$ & $\begin{array}{l}\text { Control } \\
(\mathrm{n}=50) \\
(\text { Mean } \pm \text { SD })\end{array}$ & $\begin{array}{l}\mathrm{p} \\
\text { value }\end{array}$ \\
\hline Age (years) & $56.54 \pm 12.18$ & $53.34 \pm 7.98$ & 0.124 \\
\hline $\begin{array}{l}\mathrm{SBP}(\mathrm{mm} \text { of } \\
\mathrm{Hg})\end{array}$ & $139.20 \pm 29.12$ & $117.40 \pm 12.08$ & 0.001 \\
\hline $\begin{array}{l}\mathrm{DBP}(\mathrm{mm} \text { of } \\
\mathrm{Hg})\end{array}$ & $86.20 \pm 17.59$ & $77.20 \pm 8.33$ & 0.001 \\
\hline $\begin{array}{l}\mathrm{BMI} \\
\left(\mathrm{Kg} / \mathrm{m}^{2}\right)\end{array}$ & $27.25 \pm 3.25$ & $25.38 \pm 2.57$ & 0.002 \\
\hline
\end{tabular}

Unpaired student's t-test was done to measure the level of significance; Significance $=(\mathrm{p}<0.05)$.

As shown in Table-I, mean \pm SD of age of the case and control were $56.54 \pm 12.18$ and $53.34 \pm 7.98$ respectively. There was no statistically significant difference of mean age between groups $(\mathrm{p}=0.124)$. Table-I also showed that mean \pm SD of SBP was significantly higher in cases when compared with that of controls $(\mathrm{p}=0.001)$ which were $139.20 \pm 29.12$ $\mathrm{mm}$ of $\mathrm{Hg}$ and $117.40 \pm 12.08 \mathrm{~mm}$ of $\mathrm{Hg}$ respectively. Mean \pm SD of DBP was also significantly higher in cases $(p=0.001)$ in comparison to controls and mean \pm SD of BMI was significantly higher in cases than that of controls $(\mathrm{p}=0.002)$ which were $27.25 \pm 3.25$ and $25.38 \pm 2.57 \mathrm{~kg} / \mathrm{m} 2$ respectively.

Table- II: Serum calcium level in study subjects

\begin{tabular}{|c|c|c|c|}
\hline \multirow{2}{*}{$\begin{array}{l}\text { Serum } \\
\text { calcium } \\
(\mathrm{mmol} / \mathrm{L})\end{array}$} & $\begin{array}{l}\text { Case } \\
(\text { Mean } \pm \mathrm{SD})\end{array}$ & $\begin{array}{l}\text { Control } \\
(\text { Mean } \pm \mathrm{SD})\end{array}$ & $\mathrm{p}$ value \\
\hline & $1.99 \pm 0.25$ & $2.19 \pm 0.13$ & 0.001 \\
\hline
\end{tabular}

Unpaired student's t-test was done to measure the level of significance; Significance $=(p<0.05)$.

Table-II shows mean \pm SD of serum calcium were $1.99 \pm 0.25 \mathrm{mmol} / \mathrm{L}$ and $2.19 \pm 0.13 \mathrm{mmol} / \mathrm{L}$ in cases and controls respectively and it was significantly lower in cases $(p=0.001)$.

Table-III: Serum lipid profile in study subjects

\begin{tabular}{|l|l|l|l|}
\hline $\begin{array}{l}\text { Parameters } \\
(\mathrm{mg} / \mathrm{dl})\end{array}$ & $\begin{array}{l}\text { Case } \\
(\text { Mean } \pm \mathrm{SD})\end{array}$ & $\begin{array}{l}\text { Control } \\
(\text { Mean } \pm \mathrm{SD})\end{array}$ & $\mathrm{p}$ value \\
\hline TChol & $191.64 \pm 45.01$ & $173.66 \pm 38.96$ & 0.035 \\
\hline TAG & $171.16 \pm 52.60$ & $115.34 \pm 48.33$ & 0.001 \\
\hline LDL-C & $122.50 \pm 41.53$ & $103.60 \pm 37.51$ & 0.019 \\
\hline HDL $-\mathrm{C}$ & $34.90 \pm 7.38$ & $41.10 \pm 5.98$ & 0.001 \\
\hline
\end{tabular}

Unpaired student's t-test was done to measure the level of significance; Significance $=(p<0.05)$

Table-III shows mean \pm SD of serum TChol, TAG, LDL-C and HDL-C concentrations $(\mathrm{mg} / \mathrm{dl})$ in cases were $191.64 \pm 45.01,171.16 \pm 52.60,122.50 \pm 41.53$ and $34.90 \pm 7.38$ respectively and in controls, these were $173.66 \pm 38.96,115.34 \pm 48.33,103.60 \pm 37.51$ and $41.10 \pm 5.98$ respectively. It was found that Serum TChol, TAG and LDL-C were significantly higher $(\mathrm{p}=0.035, \mathrm{p}=0.001$ and $\mathrm{p}=0.019)$ in cases when compared with those of controls. Serum HDL-C was significantly lower $(\mathrm{p}=0.001)$ in cases in comparison to controls. 


\section{Discussion:}

In the present case control study an association of biochemical risk factors such as serum calcium and lipid profile with AIS has been studied in Bangladeshi population. In this study, the mean age $\pm \mathrm{SD}$ of case and control was $56.54 \pm 12.18$ years and $53.34 \pm 7.98$ years respectively. Among the study subjects there were, 32 male and 18 female in case and 28 male and 22 female in control. The age and sex of case and control were matched and there was no statistically significant difference was found among them $(p>0.05)$. These observations are consistent with the results of the other studies ${ }^{11,12}$.

The result of the current study showed that mean \pm SD of serum calcium was $1.99 \pm 0.25$ and $2.19 \pm 0.13$ $\mathrm{mmol} / \mathrm{L}$ in acute ischemic stroke cases and healthy controls respectively. Serum calcium level was significantly lower in cases in comparison to controls. Similar result was found by the other study ${ }^{13}$.

This study also showed that the components of lipid profile - TChol, TAG, LDL-C and HDL-C in case and control had significant difference between them. The mean \pm SD of TChol, TAG, LDL-C and HDL-C of cases were 191.64 \pm 45.01 , $171.16 \pm 52.60,122.50 \pm 41.53$ and $34.90 \pm 7.38 \mathrm{mg} /$ dl respectively. The mean $\pm \mathrm{SD}$ of TChol, TAG, LDL-C and HDL-C in controls were 173.66 \pm 38.96 , $115.34 \pm 48.33,103.60 \pm 37.51$ and $41.10 \pm 5.98 \mathrm{mg} / \mathrm{dl}$ respectively. Serum TChol, TAG, and LDL-C level were significantly increased $(\mathrm{p}<0.05)$ where serum HDL-C level was found significantly decreased $(p<0.05)$ in cases when compared to controls. This result is consistent with the other studies ${ }^{14,15,16}$.

The present study suggests that high levels of serum total cholesterol, TAG, LDL-C and low level of serum HDL-C are to be associated with AIS. It also indicates that ischemic stroke patients have a lower level of serum calcium as compared to controls.

In conclusion, low serum calcium level and altered lipid profile is significantly associated with increased risk of acute ischemic stroke. So, general community should be made aware about these risk factors of stroke and regular assessment of serum calcium and lipid profile should be done which may reduce the incidence and morbidity of ischemic stroke.

Conflict of interest: None Declared.

Ethical Clearance: The protocol was approved by Research Review Committee (RRC). (DMC-MEU/ ECC/2014/99)

Source of Funding: None. 


\section{References:}

1. Feigin VL, Forouzanfar MH, Krishnamurthi R, Mensah GA, Connor M, Bennett DA et al. Global and regional burden of stroke during 1990-2010: findings from the Global Burden of Disease Study 2010. Lancet 2014; 383 (9913): 245-254. http://dx.doi.org/10.1016/S0140-6736(13)61953-4

2. Donnan GA, Fisher M, Macleod M, Davis SM. Stroke. Lancet 2008; 371:1612-1623. http://dx.doi.org/10.1016/S0140-6736(08)60694-7

3. Jauch EC. Ischemic stroke [Internet]. 2014 [updated 2015 Jan 20; cited 2014 Sep 10]. Available from: http://emedicine. medscape.com/article/1916852-overview\#a0156

4. John PW, Mark LD, Mathew WK. Plasma calcium as a predictor of cardiovascular disease in community based cohort. Clinical Endocrinology 2013; 78(6): 852-857. http://dx.doi.org/10.1111/cen.12081

5. Ferreira TdS, Torres MR, SGA, Sanjuliani AF. Dietary calcium intake is associated with adiposity, metabolic profile, inflammatory state and blood pressure, but not with erythrocyte intracellular calcium and endothelial function in healthy pre-menopausal women. British Journal of Nutrition 2013; 110(6):1079-1088. http://dx.doi.org/10.1017/S0007114513000111

6. Guven H, Clilliler A, Koker C, Sarikaky SA, Comoglu SS. Association serum calcium level with clinical severity in acute ischemic stroke. ACTA Neurologica Belgica 2011; 111: 45-49.

7. Schieszer J. High calcium levels at admission linked to better stroke outcomes [Internet]. 2007[updated 2007 Jun 03; cited 2014 Aug 1]. Available from: http://www. hcplive.com/publications/internal-medicine-worldreport/2006/2006-07/2006-07_40

8. Iso $\mathrm{H}$, Stampfer MJ, Manson JE, Rexrode $\mathrm{K}$, Hennekens $\mathrm{CH}$, Colditz GA et al. Prospective study of calcium, potassium, and magnesium intake and risk of stroke in women. Stroke, American Stroke Association journals 1999; 30 (9):1772- 1779.
http://dx.doi.org/10.1161/01.STR.30.9.1772

9. West Virginia University. Stroke Risk Factors. [Internet]. 2014 [ updated 2014 Oct 10; cited 2014 July 05] Available from: http://fh.ext.wvu.edu/r/download/23058

10. Albucher JF, Ferrieres J, Ruidavets JB, Guiraud-Chaumeil B, Perret BP, Chollet F. Serum lipids in young patients with ischemic stroke: a case-control study. Journal of Neurology, Neurosurgery \& Psychiatry 2000; 69(1): 29-33. http://dx.doi.org/10.1136/jnnp.69.1.29

11. Sorganvi V, Kulkarni MS, Udgiri R, Kadeli D, Atharga $\mathrm{S}$. Risk factors for ischemic stroke- A case control study. International journal of advanced biological research 2014; 4(1):9-12.

12. Abu-Odah H, Abed Y, Abu-Hamad B. Risk Factors of Stroke in Patients Admitted in European Gaza Hospital, Gaza Strip: A case Control Study in Medical Unit Setting. Journal of Neurological Disorders \& Stroke 2014; 2(4):15.

13. Chaudhuri JR, Mridula KR, Alladi S, Anamika A, Umamahesh M, Balaraju B et al. Serum 25-Hydroxyvitamin D Deficiency in Ischemic Stroke and Subtypes in Indian Patients. Journal of Stroke 2014; 16(1): 44-50. http://dx.doi.org/10.5853/jos.2014.16.1.44

14. Togha M, Gheini MR, Ahmadi B, Khashaiar P, Razeghi S. Lipid profile in cerebrovascular accidents. Iran Journal of Neurology 2011; 10(1-2):1-4.

15. Bowman TS, Sesso HD, Ma J, Kurth T, Kaser CS, Stampfer MJ et al. 2003. Cholesterol and the Risk of Ischemic Stroke. Stroke, American Heart Association Journals 2003; 34:2930-2934. http://dx.doi.org/10.1161/01.STR.0000102171.91292.DC

16. Farhangi MA, Ostadrahimi A, Mahboob S. Serum calcium, magnesium, phosphorous and lipid profile in healthy Iranian premenopausal women. Biochemia Medica (Zagreb) 2011; 21(3):312-320. http://dx.doi.org/10.11613/BM.2011.042 